\title{
RECORDS OF SOME RARE DEEP-SEA FISHES CAUGHT IN THE LION, SUSAN, AND UNICORN SEAMOUNTS, OFF THE ARCHIPELAGO OF MADEIRA (EAST-CENTRAL ATLANTIC)
}

\author{
João DELGADO ${ }^{1,2 *}$, Dalila CARVALHO ${ }^{1}$, Mafalda FREITAS ${ }^{3}$, Manuel BISCOITO ${ }^{3,4}$, \\ and Elisabete P. de GOUVEIA ${ }^{1}$ \\ ${ }^{1}$ Research Service, Regional Directorate of Fisheries, Funchal, Madeira, Portugal \\ ${ }_{2}^{2}$ Interdisciplinar Centre of Marine and Environmental Research, Porto, Portugal \\ ${ }^{3}$ Marine Biology Station of Funchal, MARE Sea and Environment Sciences Centre, Madeira, Portugal \\ ${ }^{4}$ OOM - Madeira Oceanic Observatory, Funchal Marine Biology Station and Marine and Environmental Sciences \\ Centre (MARE), Funchal, Madeira, Portugal
}

Delgado J., Carvalho D., Freitas M., Biscoito M., Gouveia E.P. 2017. Records of some rare deep-sea fishes caught in the Lion, Susan, and Unicorn seamounts, off the archipelago of Madeira (east-central Atlantic). Acta Ichthyol. Piscat. 47 (1): 91-96.

\begin{abstract}
Fish communities off the seamounts inside the Madeira exclusive economic zone are scarcely known, hence the need to improve this knowledge. A bottom trawl fishing survey targeting orange roughy, Hoplostethus atlanticus Collett, 1889, was carried out on the Lion, Susan, and Unicorn seamounts in the autumn of 2001. The aim of this paper is to give an account of the catches of that survey, during which 9 tows were conducted and 21 deep-sea fish species caught, including species rarely caught. The following fish species were collected: Chlamydoselachus anguineus Garman, 1884; Scymnodon ringens Barbosa du Bocage et de Brito Capello, 1864; Dalatias licha (Bonnaterre, 1788); Centrophorus squamosus (Bonnaterre, 1788); Deania profundorum (Smith et Radcliffe, 1912); Deania hystricosa (Garman, 1906); Serrivomer beanii Gill et Ryder, 1883; Rouleina maderensis Maul, 1948; Argyropelecus gigas Norman, 1930; Chauliodus sloani Bloch et Schneider, 1801; Macroparalepis nigra (Maul, 1965); Neoscopelus microchir Matsubara, 1943; Gadomus arcuatus (Goode et Bean, 1886); Mora moro (Risso, 1810); Melanonus zugmayeri Norman, 1930; Chaunax suttkusi Caruso, 1989; Diretmoides pauciradiatus (Woods, 1973); Hoplostethus mediterraneus Cuvier, 1829; Beryx splendens Lowe, 1834; Epigonus telescopus (Risso, 1810); Aphanopus carbo Lowe, 1839. The presence of Diretmoides pauciradiatus was confirmed in the area and Gadomus arcuatus was recorded for the first time from Madeira. Aspects of the life history traits of some of the species caught are presented. This includes a first approach to the estimation of the length-weight relations of 11 deep-water, data-deficient species for which prior information, estimated from data collected, did not exist in FishBase and some new insights about the biology of Hoplostethus mediterraneus.
\end{abstract}

Keywords: deep-water fishes, species composition, relative growth, life history

A growing interest emerged, in the last decades of There is also a lack of knowledge about the life the 20th century, in the development of the exploitation of deep-sea species (Merret and Haedrich 1997). During this period, commercial fishing has greatly increased the fishing effort directed to seamount-aggregated species like the orange roughy, Hoplostethus atlanticus Collett, 1889, oreos (Oreosomatidae), and alfonsinos (Beryx spp.) (see Koslow et al. 2000, Morato and Clark 2007). Although the seamount-related fisheries represent nowadays a high stake of the world deep-water fish catches, seamount research has mostly followed fisheries exploitation. Seamounts are still poorly understood habitats, among other issues concerning the living communities they support (Brewin et al. 2007). history of seamount fishes, with the majority of studies focusing on the main commercial species. Contributions on these issues are particularly important considering that seamount species, and particularly seamount-aggregating species, are more vulnerable to overfishing than other deep-sea species (Morato and Clark 2007).

Before the establishment of Exclusive Economic Zones (EEZ) in 1977, some 10 seamounts around the archipelagos of Madeira and Canaries were exploited by fishermen. The fishing gear used were mostly pelagic trawl, less frequently bottom trawl and seine. These fisheries continued intermittently after that date in the seamounts

* Correspondence: João Delgado, Direção Regional de Pescas, Serviço de Investigação, Estrada da Pontinha, $9004-562$ Funchal, Madeira, Portugal, phone: (+351) 291 203243, fax: (+351) 291 203285, e-mail: (JD) joaodelgado@gov-madeira.pt, (DC) dalilacarvalho@gov-madeira.pt, (MF) mafalda.freitas@cm-funchal.pt, (MB) manuel.biscoito@cm-funchal.pt, (EPG) elisabetegouveia@gov-madeira.pt. 
in international waters (Clark et al. 2007). Nowadays, the seamounts inside the Madeira EEZ are subject only to small scale fisheries using bottom or drifting longlines to catch demersal fishes, mostly the bathypelagicblack scabbardfish, Aphanopus carbo, and intermediate scabbardfish, Aphanopus intermedius Parin, 1983 (see Biscoito et al. 2011, Delgado et al. 2013).

In October 2001, a fishing survey was done using a commercial trawler in order to assess potential fishing opportunities for orange roughy in the seamounts inside the Madeira EEZ. The survey failed in encountering the target species, but allowed to obtain information about some rare or poorly known deep-sea fishes and provided an opportunity to gather biological data of the most commonly caught species.

The main purpose of this paper is to give an account on the species recorded in the catches of the trawling survey, including some species that are seldom caught or the presence of which in the area was doubtful until now. It also provides a contribution to the knowledge about some aspects of the life history traits of the most commonly caught species during the tows, namely its length composition and relative growth.

Fish specimens were collected during a trawl survey at depths of about $1500 \mathrm{~m}$ using a commercial trawler (F/V Pakura) within 26-31 October 2001. Nine tows taking in average 55 min were made at Unicorn, Lion, and Susan seamounts within the Portuguese EEZ near Madeira (eastern-central Atlantic) (Table 1).

The species composition of each catch was assessed before processing the specimens and the list of species is arranged taxonomically according to Nelson (2006). Whenever possible, specimens of species that are seldom caught were retained and frozen for further identification. Voucher specimens were deposited in the collection of the Funchal Natural History Museum (MMF).

For each specimen, the total length (TL) was recorded to the nearest centimetre and total weight $(W)$ and gonad weight $(\mathrm{GW})$ to the nearest gram. Whenever possible, sex and gonad development stages were determined macroscopically. Gonad development was classified according to a six-point maturity scale adapted from Holden and Raitt (1974): 0 = immature; I = recovering spent; II = early maturing, development; III = late maturing, ripening; IV = ripe; $\mathrm{V}=$ spawned, spent.

Due to insufficient number of specimens collected for the majority of species, length-weight relation (LWR) was estimated following a method suggested in Froese (2006), setting the slope to $3(b=3)$

$$
\left.a=W \times\left(L^{3}\right)^{-1}\right)
$$

and taking the geometric mean of " $a$ " for species where several specimens were available. For Hoplostethus mediterraneus, the sole species with a sufficient number of collected specimens, length-weight relation was estimated by least-square linear regression analysis of log transformed length and weight data (Bagenal and Tesch 1978)

$$
\log W=\log a+b \times \log L
$$

In this species the gonadosomatic index was obtained following the formula (King 2007)

$$
\mathrm{GSI}=100 \times \mathrm{GW} \times W^{-1}
$$

Whenever parametric tests were used to compare means, the samples were tested for normality and homogeneity of variances (respectively KolmogorovSmirnov and Levene's tests; $\alpha=0.05$ ).

A total of 197 specimens of 21 fish species, belonging to 19 families, were caught during the survey tows (Table 2). The following fish species were collected: Chlamydoselachus anguineus Garman, 1884; Scymnodon ringens Barbosa du Bocage et de Brito Capello, 1864; Dalatias licha (Bonnaterre, 1788); Centrophorus squamosus (Bonnaterre, 1788); Deania profundorum (Smith et Radcliffe, 1912); Deania hystricosa (Garman, 1906); Serrivomer beanii Gill et Ryder, 1883; Rouleina maderensis Maul, 1948; Argyropelecus gigas Norman, 1930; Chauliodus sloani Bloch et Schneider, 1801; Macroparalepis nigra (Maul, 1965); Neoscopelus

Table 1

Characteristics of the fisheries survey carried out at the Lion, Susan, and Unicorn seamounts, off the archipelago of Madeira

\begin{tabular}{lcccr}
\hline \multirow{2}{*}{ Location } & \multicolumn{3}{c}{ Beginning of tows } & Mean depth [m] \\
\cline { 2 - 4 } & Date & Hour & Coordinates & - \\
\hline Pelagic trawl & 26 Oct 2001 & $09: 01$ & $34^{\circ} 10^{\prime} \mathrm{N}, 14^{\circ} 20^{\prime} \mathrm{W}$ & 939 \\
Lion seamount & 27 Oct 2001 & $13: 50$ & $35^{\circ} 14{ }^{\prime} \mathrm{N}, 15^{\circ} 26^{\prime} \mathrm{W}$ & 1045 \\
Lion seamount & 27 Oct 2001 & $21: 16$ & $35^{\circ} 16^{\prime} \mathrm{N}, 15^{\circ} 29^{\prime} \mathrm{W}$ & 1277 \\
Lion seamount & 28 Oct 2001 & $09: 47$ & $35^{\circ} 20^{\prime} \mathrm{N}, 15^{\circ} 36^{\prime} \mathrm{W}$ & 1211 \\
Unicorn seamount & 28 Oct 2001 & $23: 20$ & $34^{\circ} 47^{\prime} \mathrm{N}, 14^{\circ} 30^{\prime} \mathrm{W}$ & 1412 \\
Unicorn seamount & 29 Oct 2001 & $15: 40$ & $34^{\circ} 49^{\prime} \mathrm{N}, 14^{\circ} 35^{\prime} \mathrm{W}$ & 695 \\
Susan seamount & 30 Oct 2001 & $20: 50$ & $32^{\circ} 45^{\prime} \mathrm{N}, 13^{\circ} 13^{\prime} \mathrm{W}$ & 1091 \\
Susan seamount & 31 Oct 2001 & $09: 36$ & $32^{\circ} 45^{\prime} \mathrm{N}, 13^{\circ} 12^{\prime} \mathrm{W}$ & 1098 \\
Susan seamount & 31 Oct 2001 & $16: 15$ & $32^{\circ} 45^{\prime} \mathrm{N}, 13^{\circ} 12^{\prime} \mathrm{W}$ & \\
\hline
\end{tabular}

Mean depth obtained from depths recorded at the beginning and end of each set. 
microchir Matsubara, 1943; Gadomus arcuatus (Goode et Bean, 1886); Mora moro (Risso, 1810); Melanonus zugmayeri Norman, 1930; Chaunax suttkusi Caruso, 1989; Diretmoides pauciradiatus (Woods, 1973); Hoplostethus mediterraneus Cuvier, 1829; Beryx splendens Lowe, 1834; Epigonus telescopus (Risso, 1810); Aphanopus carbo Lowe, 1839. The highest number of fishes caught $(86 \%)$ occurred in the Susan seamount, but the catch mainly $(82 \%)$ constituted of specimens of the Mediterranean slimehead, H. mediterraneus.

Three of the species recorded (Serrivomer beanii, Chauliodus sloani, and Macroparalepis nigra) are bathypelagic fish caught during a trial pelagic trawl.

Descriptive statistics of the size of the specimens are indicated for all the species caught and provided the values obtained for the parameter $a$ of the LWR of 20 species (Table 3).

The samples of the Mediterranean slimehead, the most abundant species, were taken from the catches obtained on the bathyal bottom in the Susan seamount, in 3 bottom trawling tows. The mean tow depths were 695, 1091, and $1098 \mathrm{~m}$. The length composition of all the individuals of $H$. mediterraneus caught is showed in Fig. 1. The size of the specimens ranged from 16 to $29 \mathrm{~cm}$ TL. The mean size
(TL) of males $(24.36 \mathrm{~cm})$ and females $(24.14 \mathrm{~cm})$ caught was equal ( $t$-test, $P>0.05$ ), however, fish caught at deeper tows $(1091 \mathrm{~m}$ and $1098 \mathrm{~m}: 24.60 \mathrm{~cm})$ had a higher mean size than fish caught at a lower depth $(695 \mathrm{~m}: 23.53 \mathrm{~cm})$ ( $t$-test, $P<0.05)$.

A relation between FL and TL (both in $\mathrm{cm}$ ), was obtained from 75 specimens: $\mathrm{TL}=1.0518 \mathrm{FL}+3.4014$; $r^{2}=0.8785 ; n=75$; the relation between TL $[\mathrm{cm}]$ and $W[\mathrm{~g}]$ in the pooled specimens was: $W=0.0088 \mathrm{TL}^{3.1533}$; $r^{2}=0.9258 ; n=141$; both relations were significant (ANOVA; $P<0.05$ ).

The analysed gonads $(n=28)$ showed a $1 \div 1$ sex ratio in an early stage of maturation (II). The respective mean GW and GSI were: $3.01 \pm 0.97$ (females), $0.76 \pm 0.25$ (males) and $1.43 \pm 0.29$ (females), $0.37 \pm 0.11$ (males).

Among the catches the presence of one specimen of Diretmoides pauciradiatus is a rare occurrence and confirms the presence of this species in the FNAM area (Whitehead et al. 1986), which was considered as doubtful by Post (1986). In the case of Gadomus arcuatus, although its occurrence was known from off the Canaries, Morocco, Azores, and Portugal (Geistdoerfer 1986, 1990, Froese and Pauly 2016) this is, to our knowledge, the first record of this species from the Madeiran waters.

Table 2

List and abundance of species caught in the fisheries survey carried out at the Lion, Susan, and Unicorn seamounts, off the archipelago of Madeira

\begin{tabular}{|c|c|c|c|c|c|c|c|c|c|c|c|}
\hline \multirow{3}{*}{ Family } & \multirow{3}{*}{ Species } & \multicolumn{9}{|c|}{ Seamounts with mean depth of tows $[\mathrm{m}]$} & \multirow{3}{*}{$\begin{array}{c}\text { Voucher } \\
\text { specimens }\end{array}$} \\
\hline & & \multicolumn{3}{|c|}{ Lion } & \multicolumn{3}{|c|}{ Susan } & \multicolumn{2}{|c|}{ Unicorn } & \multirow{2}{*}{$\frac{\text { PEL }}{-}$} & \\
\hline & & 939 & 1045 & 1277 & 695 & 1091 & 1098 & 1211 & 1412 & & \\
\hline CHLA & Chlamydoselachus anguineus & - & - & - & - & - & - & 1 & - & - & MMF33890 \\
\hline SOMN & Scymnodon ringens & - & - & 1 & - & - & - & - & - & - & \\
\hline DALA & Dalatias licha & - & 1 & - & - & - & - & - & - & - & \\
\hline \multirow[t]{3}{*}{ CENT } & Centrophorus squamosus & - & - & 1 & - & - & - & - & - & - & \\
\hline & Deania profundorum & - & 1 & - & 1 & - & 1 & - & - & - & MMF33892 \\
\hline & Deania hystricosa & - & 1 & - & - & - & - & - & - & - & MMF33891 \\
\hline SERR & Serrivomer beanii & - & - & - & - & - & - & - & - & 1 & \\
\hline ALEP & Rouleina maderensis & - & - & 6 & - & - & - & - & - & - & \\
\hline STER & Argyropelecus gigas & - & - & - & - & - & - & 1 & - & - & MMF36285 \\
\hline STOM & Chauliodus sloani & - & - & - & - & - & - & - & - & 1 & \\
\hline PARA & Macroparalepis nigra & - & - & - & - & - & - & - & - & 1 & \\
\hline NEOS & Neoscopelus microchir & - & - & - & 3 & - & - & - & - & - & MMF33893 \\
\hline MACR & Gadomus arcuatus & - & - & - & - & - & - & 1 & - & - & MMF38664 \\
\hline MORI & Mora moro & - & 1 & - & - & 1 & - & - & - & - & \\
\hline MALA & Melanonus zugmayeri & - & - & 1 & - & - & - & - & - & - & \\
\hline CHAU & Chaunax suttkusi & - & 1 & - & - & - & - & - & - & - & MMF36284 \\
\hline DITR & Diretmoides pauciradiatus & - & 1 & - & - & - & - & - & - & - & \\
\hline TRAC & Hoplostethus mediterraneus & - & - & - & 68 & 90 & 3 & - & - & - & MMF33806 \\
\hline BERC & Beryx splendens & - & - & - & 3 & - & - & - & - & - & \\
\hline EPIG & Epigonus telescopus & 1 & - & - & - & - & - & - & 1 & - & \\
\hline \multirow{2}{*}{$\underline{\text { TRICH }}$} & Aphanopus carbo & - & - & 2 & - & - & - & 2 & - & - & \\
\hline & Total & 1 & 6 & 11 & 75 & 91 & 4 & 5 & 1 & 3 & \\
\hline
\end{tabular}

$\mathrm{PEL}=$ pelagic trawl CHLA $=$ Chlamydoselachidae, $\mathrm{SOMN}=$ Somniosidae, DALA $=$ Dalatiidae, $\mathrm{CENT}=$ Centrophoridae, $\mathrm{SERR}=$ Serrivomeridae, ALEP $=$ Alepocephalidae, STER $=$ Sternoptychidae, $\mathrm{STOM}=$ Stomiidae, $\mathrm{PARA}=$ Paralepididae, NEOS= Neoscopelidae, MACR $=$ Macrouridae, MORI $=$ Moridae, MALA $=$ Melanonidae, CHAU $=$ Chaunacidae, DITR $=$ Diretmidae, TRAC $=$ Trachichthyidae, $\mathrm{BERC}=$ Berycidae, $\mathrm{EPIG}=$ Epigonidae, $\mathrm{TRICH}=$ Trichiuridae. 
Table 3

Length and weight descriptive statistics of the species caught in the fisheries survey carried out at the Lion, Susan, and Unicorn seamounts, off the archipelago of Madeira

\begin{tabular}{|c|c|c|c|c|c|c|c|c|c|}
\hline \multirow{2}{*}{ Species } & \multirow{2}{*}{$n$} & \multicolumn{3}{|c|}{ Total length [cm] } & \multicolumn{3}{|c|}{ Weight $[\mathrm{g}]$} & \multirow{2}{*}{$a$} & \multirow{2}{*}{$b$} \\
\hline & & $\mathrm{TL}$ & SD & Range & $W$ & SD & Range & & \\
\hline Chlamydoselachus anguineus & 1 & 151 & - & - & 6300 & - & - & 0.00183 & 3 \\
\hline Scymnodon ringens & 1 & 73 & - & - & 2480 & - & - & 0.00638 & 3 \\
\hline Dalatias licha & 1 & 132 & - & - & 12700 & - & - & 0.00552 & 3 \\
\hline Centrophorus squamosus & 1 & 114 & - & - & 6350 & - & - & 0.00429 & 3 \\
\hline Deania profundorum & 3 & 60 & 19.97 & $37-73$ & 926 & 686.53 & $139-1400$ & 0.00329 & 3 \\
\hline Deania hystricosa & 1 & 84 & - & - & 2100 & - & - & 0.00354 & 3 \\
\hline Serrivomer beanii & 1 & 48 & - & - & 30 & 20.97 & $51-97$ & 0.00027 & 3 \\
\hline Rouleina maderensis & 6 & 25 & 1.97 & $23-28$ & 72 & - & - & 0.00432 & 3 \\
\hline Argyropelecus gigas & 1 & 14 & - & - & 38 & - & - & 0.01384 & 3 \\
\hline Chauliodus sloani & 1 & 27 & - & - & 37 & - & - & 0.00188 & 3 \\
\hline Macroparalepis nigra & 1 & 44 & - & - & 42 & - & - & 0.00049 & 3 \\
\hline Neoscopelus microchir & 3 & 33 & 1.73 & $32-35$ & 357 & 44.52 & $325-407$ & 0.00099 & 3 \\
\hline Gadomus arcuatus & 1 & 41 & - & - & 310 & - & - & 0.00449 & 3 \\
\hline Mora moro & 2 & 42 & 2.12 & $42-43$ & 675 & 137.39 & $578-772$ & 0.00937 & 3 \\
\hline Melanonus zugmayeri & 1 & 25 & - & - & 79 & - & - & 0.00506 & 3 \\
\hline Chaunax suttkusi & 1 & 26 & - & - & 410 & - & - & 0.02333 & 3 \\
\hline Diretmoides pauciradiatus & 1 & 31 & - & - & 577 & - & - & 0.01937 & 3 \\
\hline Hoplostethus mediterraneus & 141 & 24 & 2.24 & $16-29$ & 207 & 57.24 & $50-390$ & 0.00880 & 3.153 \\
\hline Beryx splendens & 3 & 41 & 2 & $39-43$ & 923 & 222.34 & $790-1180$ & 0.01319 & 3 \\
\hline Epigonus telescopus & 2 & - & - & - & 2000 & 1414.21 & $1000-3000$ & - & - \\
\hline Aphanopus carbo & 4 & 115 & 5.56 & $109-122$ & 2105 & 166.03 & $1880-2280$ & 0.00138 & 3 \\
\hline
\end{tabular}

TL and $W$ represent mean values when $n>1, \mathrm{SD}=$ standard deviation; the parameter $a$ from the WLR was estimated setting $b=3$; Bold font denotes the fish species with no prior LWR parameters in FishBase.

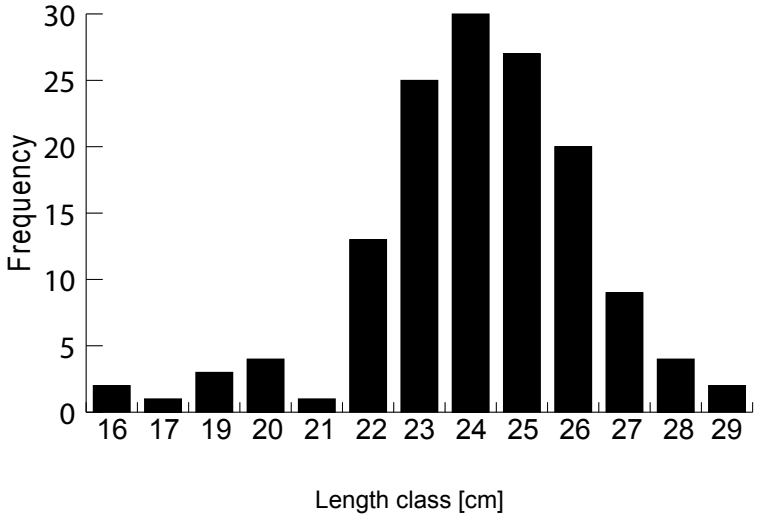

Fig. 1. Length composition of Hoplostethus mediterraneus $(n=141$; mean TL $=24.09 \mathrm{~cm})$ caught at Susan seamount, off the archipelago of Madeira

This study added information to the knowledge on the relative growth of deep water fishes considering that for 11 of the species caught (in bold in Table 3) no prior information estimated from data collection existed for LWR parameters in FishBase (Froese and Pauly 2016). In three species (S. beanii, M. nigra, and N. microchir) the value of $a$ obtained in this study is outside the range indicated by the Bayesian estimates available in FishBase following the model developed by Froese at al. (2013).

This study provides an addition to the growth data studied in demersal fish species from this area of the
Atlantic Ocean (Ferreira et al. 2007) representing a useful contribution to improve further species-specific parameter estimates in data deficient deep-sea fishes.

Concerning the Mediterranean slimehead, this species was only present in the catches made along the Susan seamount and, according to the growth performance of this species reported by D'Onghia (1998), the size composition of catches suggests all specimens caught were adult. Although young specimens were reported in catches of an experimental survey off the Greek and Italian Ionian Sea (Mytilineou et al. 2001) and from commercial trawling off South Portugal (Pais 2001), they were totally absent in this survey. The results obtained also showed an increase of the mean size of fish with depth, reflecting probable vertical segregation (the youngest up, the oldest down). This pattern was also reported by several other authors who have studied this species (D'Onghia et al. 1995, 1998, Figueiredo et al. 1995, Pais 2001, Vitale et al. 2006) and probably the cause for the absence of small sized individuals in this study, was the survey covering only depths deeper than $600 \mathrm{~m}$.

The maturity stages found (late autumn) by this study suggest a later spawning season than found by Figueiredo et al. (1995) (winter), for this species off Portugal mainland. Based on the occurrence of spent fish from autumn to spring at the same latitudes, Pais (2001) suggested a more extended spawning season, which is more in line with the data obtained in this study. 
Overall, this survey, with a few fishing hauls performed, resulted in new knowledge about the fish communities on seamounts, only confirming the need for further investigation about these ecosystems and strict conservation and management approaches to deal with activities, such as fisheries, in these peculiar and vulnerable sites that, appropriately, Pitcher et al. (2007) called: "the depths of ignorance".

\section{ACKNOWLEDGEMENTS}

Acknowledgements are due to the technicians Mr J. Silva, J. L. Figueira, J. Lucas, and N. Nóbrega, for sampling the specimens during the survey, also to R. Sousa and S. Ferreira for helping with the identification of some specimens and to the crew of the F/V Pakura for their cooperation. This study was partially supported by the Oceanic Observatory of Madeira (M1420-01-0145FEDER-000001-Observatório Oceânico da MadeiraOOM) and Fundação para a Ciência e Tecnologia (FCT), through the strategic project UID/MAR/04292/2013 granted to MARE. This is Contribution number 35 of the Funchal Marine Biology Station.

\section{REFERENCES}

Bagenal T.B., Tesch F.W. 1978. Age and growth. Pp. 101-136. In: Bagenal T. (ed.) Methods for assessment of fish production in fresh waters. Blackwell Scientific Publications, Oxford, UK.

Biscoito M., Delgado J., González J.A., Stefanni S., Tuset V.M., Isidro E., Mederos G. M., Carvalho D. 2011. Morphological identification of two sympatric species of Trichiuridae, Aphanopus carbo and A. intermedius, in NE Atlantic. Cybium 35 (1): 19-32.

Brewin P.E., Stocks K.I., Menezes G. 2007. A history of seamount research. Pp. 41-61. In: Pitcher T.J., Morato T., Hart P.J.B., Clark M.R., Haggan N., Santos R.S. (eds.) Seamounts: ecology fisheries and conservation. Fish and Aquatic Resources series Vol. 12. Blackwell Publishing, Oxford, UK.

Clark M.R., Vinnichenko V.I., Gordon J.D.M., BeckBulat G.Z., Kukharev N.N., Kakora A.F. 2007. Large-scale distant trawl fisheries on seamounts. Pp. 361-399. In: Pitcher T.J., Morato T., Hart P.J.B., Clark M.R., Haggan N., Santos R.S (eds.). Seamounts: ecology fisheries and conservation. Fish and Aquatic Resources series Vol. 12. Blackwell Publishing, Oxford, UK.

Delgado J., Reis S., González J.A., Isidro E., Biscoito M., Freitas M., Tuset V.M. 2013. Reproduction and growth of Aphanopus carbo and A. intermedius (Teleostei: Trichiuridae) in the northeastern Atlantic. Journal of Applied Ichthyology 29 (5): 1008-1014. DOI: $10.1111 /$ jai.12230

D’Onghia G., Matarrese A., Tursi A., Sion L., Panza M. 1995. Biological aspects of Hoplostethus mediterraneus (Pisces, Osteichthyes) in the Ionian Sea: reproduction and growth. Biologia Marina del Mediterraneo 2: 251-255.
D’Onghia G., Tursi A., Marano C.A., Basanisi M. 1998. Life history traits of Hoplostethus mediterraneus (Pisces: Beryciformes) from the north-western Ionian Sea (Mediterranean Sea). Journal of the Marine Biological Association of the United Kingdom 78 (1): 321-339. DOI: $10.1017 / \mathrm{S} 002531540004011 \mathrm{X}$

Ferreira S., Sousa R., Delgado J., Carvalho D., Chada T. 2007. Weight-length relationships for demersal fish species caught off the Madeira archipelago (easterncentral Atlantic). Journal of Applied Ichthyology 24 (1): 93-95. DOI: $10.1111 /$ j.1439-0426.2007.01027.x

Figueiredo M.J., Figueiredo I., Moura O. 1995. Distribution, abundance and size composition of blackbelly rosefish (Helicolenus dactylopterus) and Mediterranean redfish (Hoplostethus mediterraneus) on the slope of the Portuguese south and southern west coasts. International Council for the Exploration of the Sea CM 1995/G:10.

Froese R. 2006. Cube law, condition factor and weightlength relationships: History, meta-analysis and recommendations. Journal of Applied Ichthyology 22 (4): 241-253. DOI: $10.1111 /$ j.1439-0426.2006.00805.x

Froese R., Pauly D. (eds.) 2016. FishBase. [Version 04/2016] www.fishbase.org

Froese R., Thorson J., Reyes R.B.jr. 2013. A Bayesian approach for estimating length-weight relationships in fishes. Journal of Applied Ichthyology 30 (1): 78-85. DOI: $10.1111 /$ jai.12299

Geistdoerfer P. 1986. Macrouridae. Pp. 644-675. In: Whitehead P.J.P., Bauchot M.-L., Hureau J.-C., Nielsen J., Tortonese E. (eds.) Fishes of the North-eastern Atlantic and the Mediterranean. UNESCO, Paris, France.

Geistdoerfer P. 1990. Macrouridae. Pp. 541-563. In: Quéro J.C., Hureau J.C., Karrer C., Post A., Saldanha L. (eds.) Check-list of the fishes of the eastern tropical Atlantic. UNESCO, Lisbon, Portugal.

Holden M.J., Raitt D.F.S. 1974. Manual of fisheries science, Part-2 - Methods of resource investigation and their application. FAO Fisheries Technical Paper 115 (Rev.1).

King M. 2007. Fisheries biology, assessment and management. 2nd edn. Blackwell Publishing, Oxford, UK. DOI: $10.1002 / 9781118688038$

Koslow J.A., Boehlert G.W., Gordon J.D.M., Haedrich R.L., Lorance P., Parin N. 2000. Continental slope and deep-sea fisheries: Implications for a fragile ecosystem. ICES Journal of Marine Science 57 (3): 548-557.

DOI: $10.1006 /$ jmsc. 2000.0722

Merret N.R., Haedrich R.L. 1997. Deep-sea demersal fish and fisheries. Fish and Fisheries series. Vol. 23. Chapman and Hall, London, UK.

Morato T., Clark M.R. 2007. Seamount fishes: Ecology and life histories. Pp. 170-188. In: Pitcher T.J., 
Morato T., Hart P.J.B., Clark M.R., Haggan N., Santos R.S. (eds.) Seamounts: ecology fisheries and conservation. Fish and Aquatic Resources series Vol. 12. Blackwell Publishing, Oxford, UK.

Mytilineou Ch., Maiorano P., Kavadas S., D'Onghia G., Kapiris K., Capezzuto F. 2001. Size structure comparison in some demersal species between two areas of different fishing impact in the deep waters of eastern-central Mediterranean (Ionian Sea). NAFO SCR Doc. 01/125.

Nelson J.S. 2006. Fishes of the world. 4th Edition. John Wiley and Sons, New York, NY, USA.

Pais C. 2001. Aspects of the biology of Hoplostethus mediterraneus from the south coast of Portugal. Journal of the Marine Biological Association of the United Kingdom 81 (4): 711-712.

DOI: $10.1017 / \mathrm{S} 0025315401004477$

Pitcher T.J., Morato T., Hart P.J.B., Clark M.R., Haggan A., Santos R. 2007. The depths of ignorance: an ecosystem evaluation framework for seamount ecology, fisheries and conservation. Pp. 476-488. In: Pitcher T.J., Morato T., Hart P.J.B., Clark M.R.,
Haggan N., Santos R.S. (eds.) Seamounts: ecology fisheries and conservation. Fish and Aquatic Resources series Vol. 12. Blackwell Publishing, Oxford, UK.

Post A. 1986. Diretmidae Pp. 743-746. In: Whitehead P.J.P., Bauchot M.L., Hureau J.C., Nielsen J., Tortonese E. (eds.) Fishes of the North-eastern Atlantic and the Mediterranean. UNESCO, Paris, France.

Vitale S., Arculeo M., Aspanò E., Beltrano A.M., Bono G., Cannizzaro L., Clemente E., Manno G., Milazzo A., Rizzo P. 2006. Preliminary study on ionic composition in endolymphatic sac of Hoplostethus mediterraneus. Electronic Journal of Ichthyology 1: $12-14$.

Whitehead P.J.P., Bauchot M.-L., Hureau J.-C., Nielsen J., Tortonese E. (eds.) 1986. Fishes of the North-eastern Atlantic and the MediterraneanFNAM. Volumes 1-3. UNESCO, Paris, France.

Received: 7 October 2016

Accepted: 1 February 2017

Published electronically: 31 March 2017 